AN ANALYSIS OF SCIENTIFIC APPROACH

IN TEACHING ENGLISH AT SMA NEGERI 6 MEDAN

AN ARTICLE

Submitted in Partial Fulfillment of the Requirements

for the Degree of Sarjana Pendidikan

By:

KHAIRUNNISA FITRI NASUTION

Registration Number: 2153321011

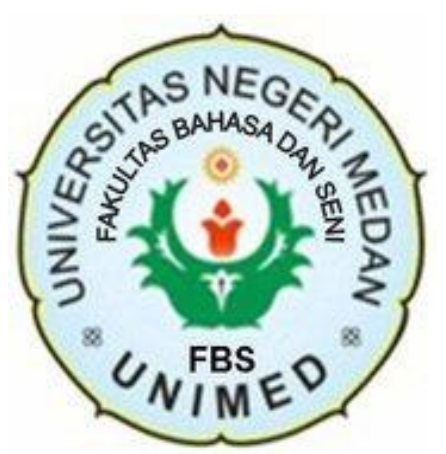

ENGLISH AND LITERATURE DEPARMENT

FACULTY OF LANGUAGES AND ARTS

STATE UNIVERSITY OF MEDAN

2020 


\title{
AN ANALYSIS OF SCIENTIFIC APPROACH \\ IN TEACHING ENGLISH AT SMA NEGERI 6 MEDAN
}

\author{
*Khairunnisa Fitri Nasution \\ **Tiarnita Maria Sarjani Siregar, S.Pd., M.Hum \\ **Puan Suri Mira Annisa, S.Pd., M.Hum
}

\begin{abstract}
Fitri, Khairunnisa. Registration Number. 2153321011. An Analysis of Scientific Approach in Teaching English At SMA Negeri 6 Medan. A Thesis. English Educational Program, State University of Medan. 2020.

This study was about an analysis of Scientific Approach in teaching English classroom. The aimed of this study were (a) to analyze the implementation of the five scientific approach in English language teaching, and (b) to find out how the teachers comprehend the concept of Scientific Approach. The subject of this research were the English teachers of SMA NEGERI 6 MEDAN. This research used descriptive qualitative research. To answer the problems of the study, the data were collected in three ways by observing, recording, and interviewing. The data were analyzed based on Miles and Huberman (1994). The result of this study were the following, (a) the first teacher was implement the observing, experimenting, and communicating process. The second teacher was implement the experimenting, associating, and communicating process. The teachers have not implemented all the five stages of Scientific Approach, (b) it found that the teachers showed lack of comprehension relating to the concept of Scientific Approach.
\end{abstract}

Keywords: Scientific Approach, 2013 Curriculum, Implementation.

\footnotetext{
*Graduate Status

**Lecturer Status
} 


\section{INTRODUCTION}

\section{A. The Background of the Study}

English becomes important subject in senior high school. One of the objectives of this policy is enabling the students to enter the world of education through English. Based on the content standard of teaching English which is issued by Badan Standar Nasional Pendidikan (BSNP), English teaching in Indonesia is aimed to help the students to achieve communicative competence (BNSP, 2006).

The changing of curriculum is, moreover, continued in 2013 which is named as the 2013 curriculum. 2013 Curriculum is a curriculum that can educate future competency, communication skills, ability to think clearly and critically, ability to consider the moral aspects of a problem (Kemdikbud, 2013).

In this curriculum, the students are encouraged to have a responsibility to the environment, interpersonal skills, and ability to think critically (Kurniasih 2014). It is characterized by the development of attitudes, knowledge, thinking skills, and psychomotor skills in a variety of subjects. Practically a curriculum that can educate students with knowledge, skill, and attitude is needed to improve the quality of education in Indonesia. 2013 Curriculum was designed to achieve this need. It should be relevant with the needs of life, developing abilities and interest, and responsive to the development of science and technology.

2013 Curriculum should be applied in the atmosphere of focusing on studentcentered learning, forming the students' self concept, increasing students' thinking skills, providing opportunities for students to assimilate and accommodate the concept, laws, and principles, and providing opportunities for students to practice the skills of communication. The implementation of 2013 Curriculum changes the teachers from a becoming source of information to be a facilitator during the teaching and learning process.

Kemdikbud (2013) states that Curriculum can be implemented successfully by using Scientific Approach. Step-by-step Scientific Approach (scientific appoach) in the learning process includes collecting information through observation, question, experiment, and then process the data or information, present data or information, followed by analyzing, reasoning, then concluded, and create.

Scientific Approach in 2013 Curriculum consists of five stages they are observing, questioning, experimenting, associating and communicating. These steps

are implemented when teachers teach the students in the classroom. Even though there have been a lot of improvement in the curriculum, in fact on the ground we still commonly find using a conventional technique in delivering the teaching such as 
lecturing and instructing These courses are lack of opportunities for the learners to engage the learners in the learning process and activity.

With this approach, Department of Education and Culture expect that the learners will be able to develop their critical thinking and apply the scientific method in solving any problems of life. With such critical thinking and problem solving skills the students are expected to be able to respond today's life challenges. In order that the students can actively develop their potentials, teachers are demanded to be able to apply Scientific Approach properly. However, in reality there are still some teachers who still get confused of how to apply the scientific approach to their teaching learning process. In fact, the data that researcher get based on the observation and also from the journals not all English teachers of Senior High School apply this approach in teaching English process. Some of the teachers do not understand this approach. Some of them said that this approach is difficult to apply and think that it is not appropriate if taught in English language teaching because of the procedures.

Based on the observation, it was found that the teachers did not always and rarely apply the Scientific Approach of 2013 Curriculum, instead the teachers still using the same method, which are the teaching was more passive, the teachers still be the center of learning, then main responsibility of teaching was on the teachers and also the students less independent. The students depend only on the teachers.

The learning process and activity are still the same as the previous curriculum and only the name of curriculum changed but the ways they teach the students, treatment, approach in the classroom are still the same. The method of teaching was only when a teacher directs students to learn through memorization and recitation techniques, for example students would sit in silence while one student after another would take it in turns to recite the lesson, until each one had been called upon.

The teacher would listen to each student's recitation, and they were expected to study and memorize the assignments. They were not developing their critical thinking, problem solving and decision-making skills. Based on the description above, the researcher needs to find out how the teachers comprehend the concept of Scientific Approach and to know more details how the teachers using the scientific approach of new curriculum at SMA NEGERI 6 MEDAN.

\section{REVIEW OF LITERATURE}

\section{A. Theoretical of framework}

This chapter provides some important terms used in this research. These terms should be elaborated and clarified in details for the readers so that both readers and writes have the same perception. 


\section{Curriculum}

\section{a. Definition of Curriculum}

In Indonesia, definition of curriculum found in Pasal 1 butir 19 UU No. 20 th. 2003 about National Education system, that Curriculum is a set of plans and arrangements about the purpose, content, teaching materials and methods used to guide the implementation of learning activities to achieve specific educational goals (Imas and Berlin, 2014). The definition of the curriculum is a device that used as a reference in developing a learning process that contains students activities to achieve a specific learning objectives and purpose of education in general.

\section{b. The Function of Curriculum}

Basically, curriculum serves as a guide or reference. For teachers, the curriculum serves as a guide in implementing the learning process. For Headmaster and supervisors, curriculum serves as a guideline in conducting supervision or oversight. For parents, the curriculum serves as a guide in guiding their children learn at home. For society, the curriculum serves as a guide to provide assistance to the educational process in schools. As for students, the curriculum serves as a study guide.

\section{2013 Curriculum}

\section{a. Definition of 2013 Curriculum}

A curriculum is an important tool to get success in education. Without an appropiate curriculum, it is difficult to reach the goal of education. In the history of education in Indonesia. Indonesia has several times in held curriculum change. Indonesia has been implementing 2013 Curriculum as the revision of previous curriculum, School-Based Curriculum (KTSP). Curriculum change based on the awareness that development and change that occur in society in Indonesia, global challenge, development of science and technology. This continuous change requires the improvement of the national education system, including the completion of the curriculum in realizing a society who is able to compete and adapt to the change.

The Decree of The Ministry of The latest curriculum used by education in Indonesia is 2013 Curriculum. The 2013 curriculum aims at preparing the Indonesia generation in order they are able to live as a faithful, productive, innovative, creative, effective, and contributive in life society, nation, state, and also civilization. Besides, one of the efforts to support the 2013 curriculum is preparing the teacher to face it. The way to make it real is the implementation of training toward the teacher in Indonesia about the 2013 curriculum. This training aims to produce the competent 
teacher in applying the scientific approach in 2013 curriculum when they are teaching. The main purpose of this curriculum is to shape the individuals who are faithful in God, good in characters, confident, successful in learning, responsible citizens and positive contributors to the civilization (Kemendikbud, 2013).

2013 Curriculum focuses on education based on competences and characters. Competence is a knowledge, skills, and abilities or capabilities that a person achieves. Students are able to perform particular cognitive, affective, and psychomotor behaviors. Mulyasa (2013) states that character in the 2013 Curriculum is a combination between manner or moral and knowledge based on competency standard in every educational unit. He also states that through the 2013 Curriculum, students are expected to increase and use their knowledge independently and review character values and attitude to apply in daily behavior.

\section{Scientific Approach}

A scientific approach is an approach which methodically acquires the knowledge based on fact rather than trusty. The revision of curriculum absolutely brings the new concept, such as the learning method, learning process, and assessment process. 2013 curriculum stressed on the pedagogic dimension in the learning which is called a scientific approach (Majid, 2013). Scientific Approach is particularly relevant to the three learning theories, namely the theory of Bruner, Piaget's theory, and the theory of Vygotsky. Bruner theory of learning is called discovery learning theory. The scientific approach is a science process-based approach that is done through the process of observing, questioning, exploring/experimenting, associating, and communicating (Permendikbud,2013).

The scientific approach helps the teacher to focus on the material of the topic that related to the students' real life and needs. This scientific approach allows teachers or curriculum developers to improve the learning process, namely by breaking the process into steps or stages in detail which contains instructions for the students carry out learning activities. The above definition shows there are specific steps in the scientific approach. The stages must be ordered and every step has a different purpose. Kemendikbud (2013) state that scientific approach is a learning process that can stimulate students to do the following skill: observing, questioning, experimenting, associating, and communicating.

\section{Observing}

The first thing to do in the scientific approach is observing. In this step, the students must observe something related to the materials. The teachers must provide the object that direct students to the materials. In this case the teacher presents a 
learning object. In the activity of observing the students can be invited to explore on the object to be studied.

\section{Questioning}

The second step is questioning. Questioning can be used by both teachers and students in the classroom. The teacher gives questions to help the students construct their idea or to confirm their understanding. The students use a questioning process to solve their confusion in the observing process. It helps them to complete information and give them more opportunity to be active.

\section{Experimenting}

Experimenting or collecting data is the third step of the processes in the learning of a scientific approach. To obtain the result of real or authentic learning, learners have to try or experiment, especially for material or substance that is appropriate. This activity serves to enable teachers and students to be active in learning. In this activity the students should find as much information from internet or other resources

\section{Associating}

To get the real or authentic learning, learners have to do experiments. For example, students should understand the concepts of greeting and parting then practice it in the real situation. They can do conversation with their friends use the expression they have learned. Associating helps the students develop knowledge about the environment, and make them able to use the scientific method and scientific attitude to solve the problems they face in everyday life. In these activities, each student is required to try to analyze what is learned.

\section{Communicating}

The last step in scientific approach is communicating. The students should communicate what they have learned. They deliver the result of their observation, the conclusion which they have got from the deep analysis. They can deliver the result orally or in the form of a written report or other media. 


\section{III.RESEARCH METHODOLOGY}

This study conducted descriptive qualitative method since main objective was to describe the scientific approach in teaching English. The descriptive method is being implemented because the data analysis has presented descriptively. The data of this study were collected by using observing, recording, and interviewing. The data of this research were the result of observational sheet when the teachers were doing the activities in English classroom and the transcript of video recording and interviewing the teachers. Source of data were the English teachers at SMA Negeri 6 Medan.

\section{RESEARCH FINDINGS AND DISCUSSIONS}

\section{a. Research Findings}

Based on the analysis of the data, the researcher found out some findings as following:

1. The finding showed that there were three Scientific Approach that occur in teaching process, the first teacher used the observing, associating and communicating. The second teacher used the process of experimenting, associating and communicating. Both teachers have not implemented the five stages of the Scientific Approach in teaching English process.

2. It was found that the teacher's comprehension about the concept of Scientific Approach still far from government expectations. It was found that the teachers showed lack of comprehension relating to the concept of Scientific Approach. The teachers were not able to manage the time when using the Scientific Approach and still did not know how the Scientific Approach should be applied in English classroom.

\section{B. Discussion}

The finding showed that there were three Scientific Approach that occur in teaching process. The Scientific Approach used by the first teacher was the observing, associating and communicating and the second teacher used the process of experimenting, associating and communicating. Both teachers did not implement the five stages of Scientific Approach and both teachers were not able to manage the time when using the Scientific Approach in teaching English process.

In the introduction activities based on the observations, the first teacher has doing the opening activities well, the first teacher had been doing the opening activities by conditioning and trying to create a pleasant learning atmosphere. In the other side the second teacher haven't doing any introduction activities. 
In the Observing process, the first teacher have done facilitating the students to do the observing in learning process. In this activity, students have given the facilitate by the teacher. The teacher already used the learning media by using the LCD projector, and then the teacher showed a video to the students so that students understand about the material that is going to learn. The second teacher have not facilitating the students to do the observing in the class and haven't using the media or video in teaching process and the teacher didn't know how to manage the observing process.

In the Questioning process, both teachers did not do the questioning process and both teachers was directly continued to the next step of learning process in Scientific Approach. Both teacher didn't guide the students to do the questioning process.

In the Experimenting process, the second teacher facilitated students to try to gather as much information about the material that being studied. The second teacher allowed the students to used their mobile phones and looked for information about the material. But the first teacher haven't done any activities of experimenting process.

In the Associating process, both teachers formed the students into several groups to further process the information that has been obtained and discussed with their group of friends. Then students also actively discussed the material and was trying to make a simple conversation based on what been taught in the class.

In the Communicating process, both teachers has done this activity by asked the students to have a simple conversation with their friends in front of the class. In closing activity process, the teacher should evaluated, and gave the students the questions, judgments and prayers, but based on the observation in the class, the first teacher gave the conclusion about material that has been learnt and the second teacher asked the students to do the homework and teacher directly left the class.

Based on the result of interviewing the English teachers, there were some reasons found behind why not all the Scientific Approach stages was being implemented in teaching learning process, because the teachers showed lack of comprehension relating to the concept of Scientific Approach and the teachers still did not know how the Scientific Approach should be applied in English classroom and also an obstacle of the application of Scientific Approach. Both teacher said that it takes a long time to do all processes in implement the Scientific Approach in classroom. 


\section{CONCLUSIONS AND SUGGESTIONS}

\section{A. The conclusions}

After analyzing the data, the researcher concluded that there were three Scientific Approach that occur in the teaching process. The first teacher was implement the observing, associating, and communicating process of Scientific Approach and the second teacher was implement the experimenting, associating and communicating process. The first teacher did not implement the questioning and experimenting process and the second teacher did not implement the observing, and questioning process of Scientific Approach. Both teachers did not implement all the five stages of Scientific Approach process in the classroom. It was found that the teachers showed lack of comprehension relating to the concept of Scientific Approach. The teachers were not able to manage the time when using the Scientific Approach still did not know how the Scientific Approach should be applied in English classroom.

\section{B. Suggestions}

There were some suggestions given for the consideration the future, for the teacher is expected to apply all the five process of Scientific Approach in teaching English process. The teachers should know the concept of Scientific Approach and be able to manage the time when using the Scientific Approach and the teachers should ask the students more questions when teaching in class. For students, the students should be dare to speak up and be active in learning process and less passive when teacher asked them the questions. For next researchers, the researcher suggested to other researchers to conduct varied research and futher studies in other school or classroom which will be a very useful reference to the teachers and students in teaching and learning process. 


\section{REFERENCES}

Ashar, Irmawati. 2016. English Language Teaching In Secondary School: An Analysis Of The Implimentation Of Indonesian ELT 2013 Curriculum.

Ashar. Irmawati. 2016. The Implementation Of The 2013 Curriculum Of English at SMKN 1 Bantaeng: An Evaluative Study. Vol 3. International Journal of English Education Graduate Program.

Brown, H. Douglas. 2001. Teaching By Principle: An Interactive Approach To Language Pedagogy. Newyork:Longman.

Brown. H. Douglas. 2007. Prinsip Pembelajaran dan pengajaran Bahasa. Jakarta:Pearson Education,Inc.

BSNP. 2006. Kurikulum 2006. Jakarta. Dapertemen Pendidikan Nasional.

Burns. 1999. Collaborative Action Research For English Language Teachers. United Kingdom. Cambridge University Press.

Daryanto. 2014. Pendekatan Pembelajaran Scientific Kurikulum 2013. Yogyakarta: Penerbit Gava Media.

Harmer. 2007. The Practice Of English Language Teaching. Cambridge.Forth Edition.

Imas. 2014. Implementasi Kurikulum 2013 Konsep dan Penerapan.Surabaya: Kata Pena.

Kemendikbud. 2013. Peraturan Menteri Pendidikan dan Kebudayaan Tentang Implementasi Kurikulum 2013. Jakarta: Kementrian Pendidikan dan Kebudayaan.

Kemendikbud. 2014. Konsep dan Implementasi Kurikulum 2013. Jakarta: Kementrian Pendidikan dan Kebudayaan.

Kemendikbud. 2016. Peraturan Menterin Pendidikan dan Kebudayaan Tentang Standar Isi Untuk Satuan Pendidikan.

Kurnasih, Sani. 2015. Model Pembelajaran. Yogyakarta: Kata Pena.

Kwek. S,H. 2011. Innovation In The Classroom: Design Thinking For 21st Century.

Lazim. 2013. Penerapan Pendekatan Scientific Dalam Pembelajaran Kurikulum 2013. www.pppgkes.com. Diakses Hari Sabtu. 11 Juni 2019 
M.Zaim. 2017. The Implementation of Scientific Approach In Teaching English At The Tenth Grade Of Senior High School 7 Padang. UNP. Journals Vol XVII No.1. Maret 2016 Hal 1-18

Majid. 2013. Strategi Pembelajaran. Bandung :Remaja Rosdakarya.

Mulyasa. 2013. Pengembangan dan Implementasi Kurikulum 2013.Bandung: Rosdakarya .

Mulyoto. 2013. Strategi Pembelajaran Di Era Kurikulum 2013.Jakarta:Prestasi Pustakaraya.

Murray and Christison. 2011. What English Teachers Need To Know Facilitating Learning .Vol 2. Newyork: Roudledge.

Miles and Huberman. 1994. Qualitative Data Analysis:An Expanded Source Book. Thousand Oaks. CA: Sage Publications.

Permendikbud. 2013. 81A Tentang Implementasi Kurikulum. Jakarta: Kementrian Pendidikan dan Kebudayaan.

Priyana. 2014. Language Learning Activities in Proceedings of The 61st TEFLIN International Conference. TEFLIN.

Sugiyono. 2009. Metode Kuantitatif, Kualitatif, dan R\&D. Bandung: Alfabeta.

Suharyadi. 2013. Exploring "Scientific Approach" In English Language Teaching. Malang: Universitas Negri Malang.

Tomlison. 1998. Materials Development In Language Teaching. Cambridge : Clip.

Trisnawati, Reni. 2015. The Implementation of Scientific Approach in Teaching English Speaking (A Descriptive Study to the Seventh Grade Students of SMP Nurul Islam Ngemplak in 2014/2015 Academic Year). Thesis: IAIN Surakarta.

Utami, Septi. 2014. A Descriptive Study of the Implementation of Curriculum 2013 in the Teaching and Learning of Reading at the Seventh Grade Students of MTs Negeri Pedan in 2014/2015 Academic Year. Thesis: IAIN Surakarta

Widodo. 2015. Dasar Pengembangan Kurikulum Sekolah.

Yulia Nur Ekawati. 2017. English Teacher's Problems In Applying The 2013 Curriculum. Vol 6. December 2017. Journal of English Education.

Zaim. 2014. The Development Of Character Education Curriculum. International Journal of Education and Research. Vol 2 No. 6 June 2014. 